Rapp. Grønlands geol. Unders. 81, 35-51 (1977)

\title{
TERTIARY VOLCANIC GEOLOGY OF THE MELLEMFJORD AREA, SOUTH-WEST DISKO
}

\author{
Asger Ken Pedersen
}

\begin{abstract}
Introduction
This paper reports on the results of three weeks of investigations in the Mellemfjord-Eqaluit area of south-west Disko, carried out in the summer of 1974. Very little has been published on the geology in this area: Steenstrup $(1882,1883,1900)$ described the area briefly and concentrated on native iron bearing lavas, from which samples were petrographically decribed by Lorenzen (1882), Nicolau (1900), and Pauly (1969), who also communicated results from an unpublished field report by W. Fisch. The purpose of the present investigation was threefold, namely the study of the youngest exposed volcanic rocks on Disko, the study of native iron bearing volcanic rocks and the study of the structure of the coast area which is of interest for the interpretation of the off-shore geology.
\end{abstract}

\section{General geology}

The Mellemfjord region is a typical, arctic, plateau basalt landscape with well exposed cirque carved lava plateaus and U-shaped valleys and fjords. The land surface rises gradually from the coast of Disko eastwards and mountain tops reach altitudes higher than 1000 $m$ in the inner part of Mellemfjord. The pre-Quaternary consists entirely of an originally nearly horizontal sequence of Tertiary lavas with very subordinate tuffs. Interbasaltic conglomerates are absent. The volcanic rocks are underlain by unexposed sediments of possible Mesozoic and early Tertiary age which appear only as xenoliths in some volcanic rocks. Along the coast and into the valleys several generations of marine terraces record a number of Quaternary events, ending with the fairly recent formation of mud volcanoes. Prominent Quaternary features have been mapped, but will not be described here.

The Tertiary basalts contain many marker horizons and although these are sometimes inaccessible in the field, the basalt sequence is so well suited for photogrammetrical observations that a geological map sheet at scale 1:50000 has been compiled using high-precision photogrammetrical methods, described by Dueholm, Pedersen \& Ulff-Møller (this report). The map sheet with two profiles is presented as Plate 1. 
Table 6. Summary of basalt stratigraphy in south-western Disko

\begin{tabular}{|c|c|c|c|}
\hline Formation & Member & Dominant lithology & Thickness \\
\hline & Niaqussat member & Olivine porphyritic basalts & \\
\hline & & Feldsparphyric basalts & \\
\hline Maligât & & Olivine microporphyritic basalts & $600 \mathrm{~m}$ \\
\hline \multirow[t]{4}{*}{ Formation } & & $\begin{array}{l}\text { Sediment contaminated iron-bearing basalt } \\
\text { and intermediate rocks }\end{array}$ & exposed \\
\hline & Nordfjord member & Feldsparphyric basalts & \\
\hline & & $\begin{array}{l}\text { Sediment contaminated basalts and } \\
\text { intermediate rocks }\end{array}$ & $50-150 \mathrm{~m}$ \\
\hline & Rinks Dal member & Feldsparphyric plateau basalts & $\begin{array}{r}800 \mathrm{~m} \\
\text { exposed }\end{array}$ \\
\hline
\end{tabular}

\section{Maligât Formation}

All the exposed volcanic rocks represent a sequence about $1.5 \mathrm{~km}$ thick belonging to the Maligât Formation (Hald \& Pedersen, 1975). Representative sections through the lavas are presented as fig. 17; the stratigraphy is summarized in Table 6. Pending adequate definition, the subdivisions of this formation into members (also used to describe the lavas of north-western Disko (Pedersen, 1975a)) will be regarded as informal usage.

\section{Rinks Dal member}

About $800 \mathrm{~m}$ of feldsparphyric plateau basalts belonging to the upper part of the Rinks Dal member are exposed within the area and appear as a monotonous sequence of typically 20-25 $\mathrm{m}$ thick brownish aa lavas, some of which may be very voluminous. While the basalts contain few or no usable marker horizons for regional photogrammetrical mapping, detailed investigations may easily establish local marker horizons, as shown from mapping of Rinks Dal member basalts in Hammers Dal (Ulff-Møller, this report).

Rinks Dal member basalts make up most of the exposed lava plateau along the south coast of Disko as far east as Godhavn, where the lower part of the member is developed as subaqueous lava tongues and cross-bedded pillow breccias, formed from subaerial lava flows extending into shallow water. Within the mapped area sedimentary beds are missing or very scarce and only appear as thin tuffs or red boles. Dykes, petrographically resembling the lavas, occur, but such dykes feeding lavas have not been observed. Further north, however, a volcanic neck feeding Rinks Dal member basalts has been localized on the inner part of the south coast of Nordfjord.

It seems that upwelling from depth of the basalts occurred over large areas. Thus cross-bedded Rinks Dal member pillow breccias in the Godhavn area indicate outpouring of such basalts both from the east and the west of the N-S trending, extensive water-filled depressions found east of the Disko gneiss ridge. Samples analysed from dredges more than $70 \mathrm{~km}$ south of Disko by Clarke (1975) are compositionally identical to Rinks Dal member basalts. 
Niaqussat member

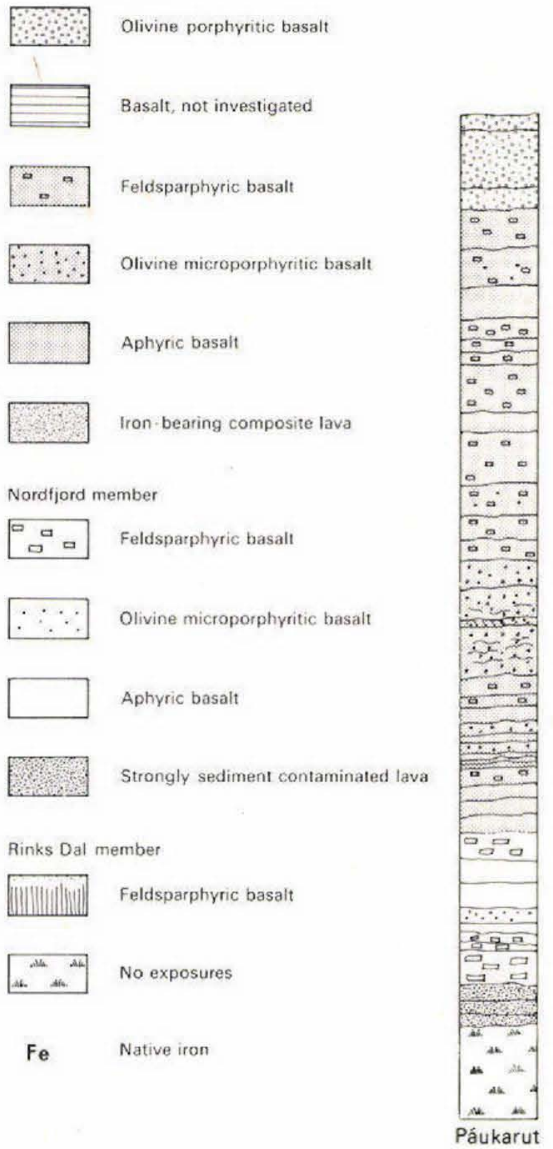
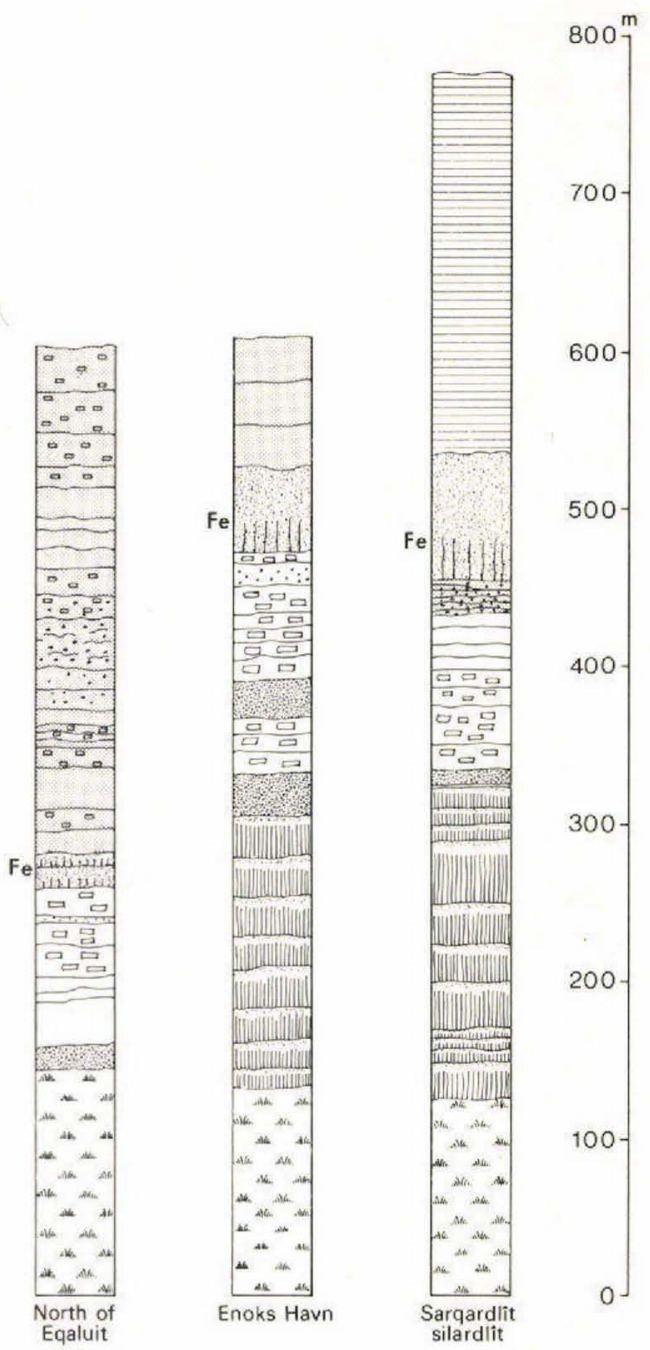

Fig. 17. Profiles showing the volcanic succession in south-western Disko. The profiles were obtained combining photogrammetrical measurements with detailed field observations. Parts of the profiles were neither visited in the field nor measured and are shown only schematically.

Petrographically, the Rinks Dal member basalts are tholeiites, slightly olivine or quartznormative. Plagioclase is the dominant phenocryst phase occurring together with olivine (normally pseudomorphed in most lavas but preserved in pillow breccias) and augite. Olivine is scarcer in the upper than in the lower part of the member. Chromite is absent. Phenocrysts rarely attain $5 \mathrm{~mm}$ in size and megacrysts are absent. Two typical chemical analyses are given in Table 7 , no. $1 \& 2$. The Rinks Dal member basalts compare well with but are slightly more evolved than the Nuluk member basalts forming the lower part of the Maligât Formation of western Nûgssuaq (Hald, 1976), but the Nûgssuaq lavas are much thinner. 
Table 7. Chemical analyses of lavas from the Rinks Dal and Nordfjord members

\begin{tabular}{|c|c|c|c|c|c|c|c|}
\hline & 1 & 2 & 3 & 4 & 5 & 6 & 7 \\
\hline $\mathrm{SiO}_{2}$ & 48.92 & 49.72 & 52.55 & 52.93 & 62.86 & 52.57 & 49.75 \\
\hline $\mathrm{TiO}_{2} \ldots \ldots \ldots \ldots \ldots \ldots \ldots \ldots \ldots \ldots$ & 2.47 & 2.66 & 2.17 & 2.18 & 2.27 & 1.83 & 2.72 \\
\hline $\mathrm{Al}_{2} \mathrm{O}_{3} \ldots \ldots \ldots \ldots \ldots \ldots \ldots \ldots \ldots$ & 14.18 & 13.89 & 15.17 & 15.11 & 12.82 & 15.13 & 14.05 \\
\hline $\mathrm{Fe}_{2} \mathrm{O}_{3} \ldots \ldots \ldots \ldots \ldots \ldots \ldots$ & 4.10 & 1.62 & 1.84 & 2.02 & 1.05 & 1.22 & 5.28 \\
\hline $\mathrm{FeO} \ldots \ldots \ldots \ldots \ldots \ldots \ldots \ldots \ldots$ & 9.08 & 10.62 & 8.40 & 8.15 & 8.88 & 8.62 & 7.46 \\
\hline $\mathrm{MnO} \ldots \ldots \ldots \ldots \ldots \ldots \ldots \ldots \ldots \ldots \ldots$ & 0.23 & 0.21 & 0.19 & 0.17 & 0.16 & 0.18 & 0.19 \\
\hline $\operatorname{MgO} \ldots \ldots \ldots \ldots \ldots \ldots \ldots \ldots$ & 6.17 & 6.43 & 6.12 & 5.81 & 2.03 & 6.50 & 6.06 \\
\hline $\mathrm{CaO} \ldots \ldots \ldots \ldots \ldots \ldots \ldots \ldots$ & 11.19 & 10.84 & 9.72 & 9.50 & 6.34 & 9.71 & 10.54 \\
\hline $\mathrm{Na}_{2} \mathrm{O} \ldots \ldots \ldots \ldots \ldots \ldots \ldots \ldots$ & 2.44 & 2.45 & 2.52 & 2.54 & 2.45 & 2.17 & 2.74 \\
\hline $\mathrm{K}_{2} \mathrm{O} \ldots \ldots \ldots \ldots \ldots \ldots \ldots \ldots \ldots$ & 0.20 & 0.34 & 0.51 & 0.93 & 0.85 & 0.36 & 0.51 \\
\hline $\mathrm{P}_{2} \mathrm{O}_{s} \ldots \ldots \ldots \ldots \ldots \ldots \ldots \ldots \ldots \ldots \ldots \ldots$ & 0.24 & 0.23 & 0.24 & 0.23 & 0.54 & 0.16 & 0.27 \\
\hline \multirow[t]{2}{*}{ 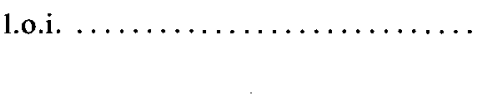 } & $\underline{1.12}$ & 0.76 & 0.79 & 1.07 & 1.69 & $\underline{1.30}$ & $\underline{0.83}$ \\
\hline & 100.34 & 99.77 & 100.23 & 100.64 & 99.94 & 99.75 & 100.38 \\
\hline Total $\mathrm{Fe}$ as $\mathrm{FeO} \ldots \ldots \ldots \ldots \ldots$ & 12.77 & 12.08 & 10.06 & 9.97 & 7.82 & 9.72 & 12.21 \\
\hline $\mathrm{Cr}$ in ppm $\ldots \ldots \ldots \ldots \ldots \ldots \ldots$ & 128 & 147 & 362 & 355 & 62 & 616 & 190 \\
\hline $\begin{array}{l}\mathbf{M g} /(\mathbf{M g}+\text { Fetotal }) \\
\text { (in cation } \%) \ldots \ldots \ldots \ldots \ldots \ldots \ldots\end{array}$ & 0.46 & 0.49 & 0.52 & 0.51 & 0.32 & 0.54 & 0.47 \\
\hline \multicolumn{8}{|l|}{ CIPW norm (in weight \%) } \\
\hline $\mathrm{Q} \ldots \ldots \ldots \ldots \ldots \ldots \ldots \ldots \ldots \ldots \ldots \ldots \ldots$ & 0.15 & 1.23 & 5.15 & 4.89 & 27.86 & 6.67 & 0.09 \\
\hline or $\ldots \ldots \ldots \ldots \ldots \ldots \ldots$ & 1.18 & 2.01 & 3.01 & 5.50 & 5.02 & 2.13 & 3.01 \\
\hline$a b$ & 20.65 & 20.73 & 21.32 & 21.49 & 20.73 & 18.36 & 23.18 \\
\hline an $\ldots \ldots \ldots \ldots \ldots \ldots \ldots \ldots \ldots \ldots \ldots \ldots \ldots$ & 27.15 & 25.90 & 28.58 & 27.08 & 21.47 & 30.48 & 24.53 \\
\hline 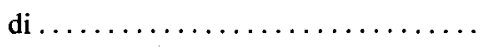 & 22.18 & 21.74 & 14.78 & 15.24 & 5.43 & 13.64 & 21.57 \\
\hline hy $\ldots \ldots \ldots \ldots \ldots \ldots \ldots \ldots \ldots \ldots \ldots$ & 19.98 & 19.51 & 19.92 & 18.72 & 10.67 & 21.48 & 18.72 \\
\hline $\mathrm{mt} \ldots \ldots \ldots \ldots \ldots \ldots \ldots \ldots \ldots \ldots \ldots$ & .2 .45 & 2.32 & 1.93 & 1.91 & 1.49 & 1.86 & 2.33 \\
\hline il $\ldots \ldots \ldots \ldots \ldots \ldots \ldots \ldots \ldots \ldots \ldots$ & 4.69 & 5.05 & 4.12 & 4.14 & 4.31 & 3.48 & 5.17 \\
\hline ap $\ldots \ldots \ldots \ldots \ldots \ldots \ldots \ldots \ldots \ldots \ldots \ldots \ldots$ & 0.57 & 0.54 & 0.59 & 0.54 & 1.28 & 0.38 & 0.59 \\
\hline $\begin{array}{l}\text { Katanormative plagioclase } \\
\text { composition as per cent }\end{array}$ & & & & & & & \\
\hline of anorthite $\ldots \ldots \ldots \ldots \ldots \ldots \ldots$ & 55.34 & 54.07 & 55.84 & 54.25 & 49.37 & 60.99 & 49.92 \\
\hline
\end{tabular}

Norms have been calculated with $\mathrm{Fe}_{2} \mathrm{O}_{3} / \mathrm{FeO}=0.15$. This ratio is found in glassy feldsparphyric basalts of the Rinks Dal member and in basaltic glasses separated from these samples.

Analyst: GGU's chemical laboratory, except for $\mathrm{Cr}$ and $\mathrm{P}_{2} \mathrm{O}$ s.

1156757 Feldsparphyric tholeiitic basalt from the Rinks Dal member, second lava above the sediments, Pingo, eastern Disko.

2176765 Outer glassy zone of pillow fragment of olivine, feldspar and augite porphyritic basalt in pillow breccia from the Rinks Dal member. $5 \mathrm{~m}$ above sea level at Qeqertaluk below Skarvefjeld, southern Disko.

3176626 Nearly aphyric sediment contaminated basalt, lowermost lava from the Nordfjord member. About $3 \mathrm{~km}$ west of Enoks Havn, near the coast at $120 \mathrm{~m}$.

4176579 Nearly aphyric sediment contaminated basalt. About $1.5 \mathrm{~m}$ above the base of composite lava, which may have been iron bearing. Basal part of Nordfjord member below point 370 about $3 \mathrm{~km} \mathrm{NE}$ of Eqaluit at $275 \mathrm{~m}$. 
Elder (1975) has found geophysical evidence for a very rapid thinning of the continental crust in western Nûgssuaq. Nothing indicates such a thinning in southern Disko and the difference in lava thickness in chemically similar basalts may have been caused by the greater tendency for reservoir building under a thick crust.

\section{Nordfjord member}

The Nordfjord member volcanic rocks form a small sequence of sediment contaminated lavas, in total from 150 to less than $50 \mathrm{~m}$ thick. While the Nordfjord member in northwestern Disko contains acid tuffs and sometimes pitch-stone-bearing conglomerates (Pedersen, 1975a), such rocks are absent within the Mellemfjord area.

\section{The basal marker horizon of contaminated lava}

At the base of the member there is a light greyish weathering aa lava (fig. 18) often displaying a highly oxidized flow top. This lava has been photogrammetrically mapped as a prominent marker horizon (Plate 1). It is possible that the marker horizon consists of several similar-looking lavas, erupted from different sites within the area. Some of these lavas are possibly separated in time by eruption of a few feldsparphyric basalts. The lava unit varies from less than 10 to more than $25 \mathrm{~m}$ in thickness and covers an area of at least $420 \mathrm{~km}^{2}$. A minimum estimated volume exceeds $6 \mathrm{~km}^{3}$.

Fig. 18. Composite sediment contaminated lava from the basal part of the Nordfjord member. Point $370, \mathrm{NE}$ of Eqaluit.

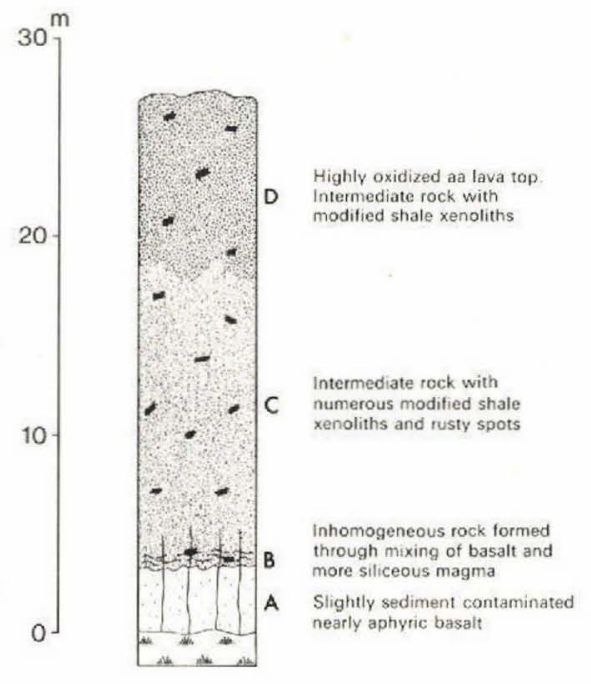

Table 7 cont.

5176555 Grey nearly aphyric, intermediate rock from lowermost lava of the Nordfjord member. Steep cleft just north of the ruins of Sarqardlît ilordlit at $850 \mathrm{~m}$, inner part of Mellemfjord.

6176551 Aphyric sediment contaminated basalt from the middle part of the Nordfjord member.

Mountain slope just east of Enoks Havn at $390 \mathrm{~m}$.

7176567 Feldsparphyric basalt from middle part of the Nordfjord member. Cleft at $390 \mathrm{~m}, 3.5 \mathrm{~km}$ west of Sarqardlit silardlit, Outer Mellemfjord. 
Over most of the area, the unit is composed of nearly aphyric basalt with a very finegrained groundmass and few microphenocrysts of orthopyroxene and plagioclase. A few xenoliths of spinel-plagioclase-graphite rock (highly modified shaly sediments) may occur together with a variety of xenocrysts. The lava may show flow structures and is chemically highly inhomogeneous. In the area about $3 \mathrm{~km}$ north-east of Eqaluit, the unit appears as a composite lava, schematically shown in fig. 18. The lower few metres are here a columnar jointed, nearly aphyric basalt. It grades through a $8-10 \mathrm{~cm}$ thick transition zone up into a thick more siliceous part rich in rusty spots, which may have been native iron and/or sulphides. From the transition zone and upwards, cognate pyroxene-plagioclase inclusions are common together with modified sediment xenoliths.

Chemical analyses of three samples from the unit from various localities within the area are presented in Table 7, no. 3,4 and 5. The analyses are all quartz normative and the most siliceous rock combines very high normative quartz with a fairly basic normative feldspar (An 49). All the rocks are chemically contaminated through reaction with sediments; nevertheless a parent magma with a fairly high $\mathrm{TiO}_{2}$ and a low $\mathrm{MgO}$ content can still be recognized. It seems to have been slightly more mafic than the Rinks Dal member basalt with a chromium content above $350 \mathrm{ppm}$, but otherwise rather similar.

\section{Feldsparphyric basalts}

The overlying part of the Nordfjord member is normally formed by fewer than ten flows of basaltic lavas. Most characteristic is a basalt lava type rich in phenocrysts of plagioclase in addition to minor augite and pseudomorphed olivine. The plagioclase phenocrysts are typically 2 to $6 \mathrm{~mm}$ in size and exceed in size and sometimes in amount (15\%) plagioclase phenocrysts in all feldsparphyric basalts of both the Rinks Dal member and the overlying Niaqussat member. The lava type has been found in the Nordfjord member along the entire west coast of Disko. A chemical analysis is given in Table 7, no. 7 and shows a tholeiitic basalt, slightly more potassic than typical Rinks Dal member basalts. Chemically, the rock does not appear to be feldspar cumulative. The large size of the phenocrysts, together with evidence from scattered sediment-derived xenocrysts indicates that this lava type evolved in high level magma reservoirs during stagnating eruptive conditions. The upper part of the Nordfjord member may also include nearly aphyric basalts with or without sediment xenoliths. Such a rock analysis is given in Table 7, no. 6 .

\section{Summary}

In summary, the Nordfjord member volcanism was characterized by upwelling through the crust of feldsparphyric tholeiitic melts slightly more mafic than the Rinks Dal member basalts. Stagnating eruptive conditions led to the development of magma reservoirs in sediments. Subsequent eruptions (whose precise eruption sites are not know) led to the formation of feldsparphyric basalts, siliceous basalts and intermediate rocks. This volcanic event was recorded along the entire west coast of Disko, but only from Nordfjord and northwards are acid volcanic rocks found among the eruption products. 


\section{Niaqussat member}

Niaqussat member volcanic rocks form a rather variable sequence, more than $600 \mathrm{~m}$ thick. Within the Mellemfjord area the unit includes a prominent native iron bearing lava at the base; the middle part of the member consists of aphyric, olivine-microporphyritic basalts and feldsparphyric basalts, and the youngest part is composed of olivine porphyritic basalts.

\section{The native iron bearing composite lava}

An extensive native iron-bearing lava flow occurs at the base of the Niaqussat member. It has been mapped as a prominent marker horizon on the map (Plate 1) and the papers cited at the beginning of the article all deal with this lava. The iron-bearing lava was emplaced through a major eruption, and since it is the most continuously exposed of all the iron-bearing lavas of Disko, it will described in considerable detail. Photogrammetric measurements of the thickness of the lava were obtained from 48 localities and a very crude isopach map constructed as fig. 19. A limitation in the interpretation of the lava is that in distal parts of the lava it becomes photogrammetrically indistinguishable from other basalts.

The measurements show that:

(1) the volume of the lava may be estimated at about $14 \mathrm{~km}^{3}$. This is a conservative estimate, since only areas close to the coast are included.

(2) The lava covers an area of more than $400 \mathrm{~km}^{2}$, and its widespread development indicates that the eruption occurred on a nearly horizontal plane.

(3) The lava flow exceeds $80 \mathrm{~m}$ in thickness around the outer north coast of Mellemfjord and may have had its major upwelling site within this area or maybe slightly off-shore near the classical locality of Jernpynten, found by Steenstrup (1882).

(4) The isopachs indicate a slight tendency for a NW-SE extension. This corresponds to the most prominent zone of dyke intrusion found in northern and western Disko. The intrusion of these dykes was followed by the formation of combined volcanic neck dyke systems of other iron-bearing Niaqussat member volcanic suites such as the Hanekammen and the Hammers Dal complexes of north-western Disko (Pedersen, 1975a). However, although a fissure or a combined neck fissure feeding system is thus indicated, no actual feeders have yet been discovered.

The lower part of the lava is basaltic in composition. Around the presumed eruption site west of Sarqardlit silardlit, several lava flows of an olivine microporphyritic basalt are present just below the iron-bearing lava and seem to have originated from the same eruption. These lavas show a highly irregular upper surface (fig. 20). At some places large heaps of scoria have been found, while piles of thin pahoehoe tongues have been seen nearby. The lavas may carry a varying amount of cognate gabbroic pyroxene-olivine-plagioclase inclusions, up to $5 \mathrm{~cm}$ in size, together with modified sedimentary xenoliths. A chemical analysis is given in Table 8, no. 1 .

The basal few decimetres of the iron-bearing lava are composed of olivine and feldspar microphyric basalt, which contains neither sulphides nor native iron. The chemical composition (Table 8, no. 2) strongly resembles the underlying lava.

The basalt grades up into an iron-bearing, intermediate rock, sometimes showing very 


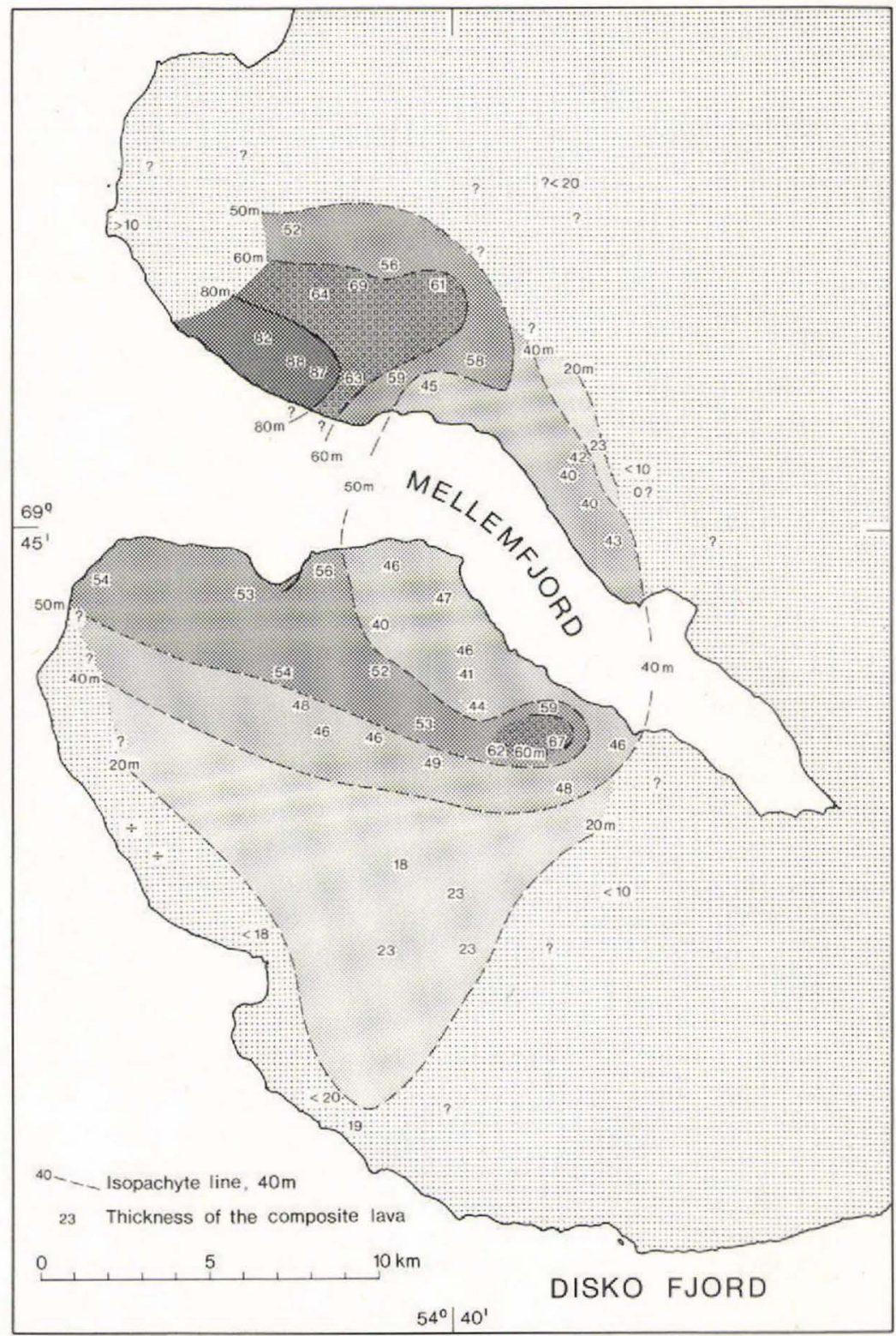

Fig. 19. Isopach map showing the variation in thickness of the composite iron-bearing lava at the base of the Niaqussat member. Accuracy of thickness measurements is about $\pm 2 \mathrm{~m}$, depending on the exposures. 


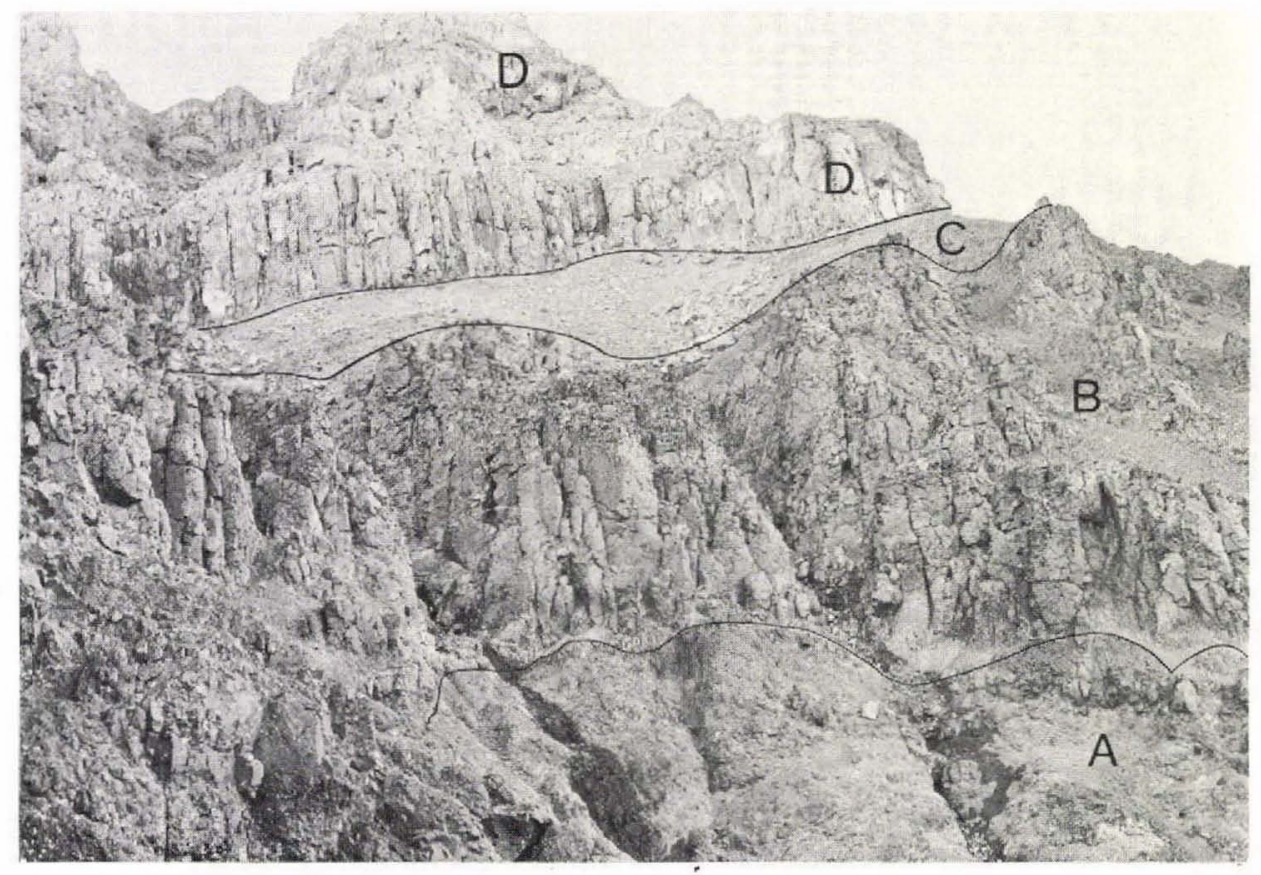

Fig. 20. The extensive iron-bearing lava near the presumed eruption site west of Sarqardlit silardlit. The base of the flow rests on irregular large heaps of oxidized scoria alternating with pahoehoe tongues of basalt. A: basaltic lava and scoria, B: columnar jointed iron-bearing intermediate rock, C: oxidized crumbly, highly vesicular aa lava at the top of the iron lava, D: Niaqussat member basalts covering the iron-bearing lava.

coarse columnar jointing, containing scattered modified xenoliths, abundant pyrometamorphic sediment-derived xenocrysts together with phenocrysts of plagioclase and low-Ca clinopyroxene and orthopyroxene in a dense groundmass. The rock is petrographically described by Nicolau (1900). The native iron occurs as discrete bodies up to a few millimetres across and is described in detail by Pauly (1969). Samples taken from a few metres above the base up to the top show a very restricted chemical variation over large areas. An analysis (Table 8 , no. 3 ) shows an intermediate rock with a high normative silica content and with a high hy/di ratio. It is characterized by a much higher $\mathrm{MgO}$ and much lower $\mathrm{TiO}_{2}$ content than strongly contaminated rocks from the Nordfjord member. The $\mathrm{Cr}$ content of about $400 \mathrm{ppm}$ is unusually high for intermediate rocks and is due to the comparatively high solubility of $\mathrm{Cr}$ in reducing magmas. The top of the lava is scoriaceous and highly oxidized. Fig. 21 shows the lava as it appears from a distance.

Far from the eruption site, the iron-bearing lava flow may appear as one or two ironbearing pahoehoe lavas of basaltic composition throughout as found in the Eqaluit area. Native iron and sulphides show igneous accumulation towards the base of these lavas. A chemical analysis is given in Table 8, no. 4 . The absence of the voluminous siliceous rock in the distal parts of the lava is presumably a consequence of the much higher viscosity of such magmas compared to the basaltic magmas. 
Table 8. Chemical analyses of lavas from the Niaqussat member

\begin{tabular}{|c|c|c|c|c|c|c|c|c|c|c|c|c|c|}
\hline & 1 & 2 & 3 & 4 & 5 & 6 & 7 & 8 & 9 & 10 & 11 & 12 & 13 \\
\hline $\mathrm{SiO}_{2} \ldots$ & 48.47 & 49.90 & 59.93 & 52.28 & 49.39 & 46.68 & 47.03 & 49.23 & 48.94 & 51.02 & 47.27 & 48.21 & 46.60 \\
\hline $\mathrm{TiO}_{2} \ldots \ldots \ldots \ldots$ & 1.55 & 1.62 & 1.11 & 1.43 & 1.67 & 1.34 & 1.58 & 1.77 & 2.42 & 2.41 & 1.15 & 1.55 & 0.82 \\
\hline $\mathrm{Al}_{2} \mathrm{O}_{3}, \ldots \ldots \ldots \ldots \ldots \ldots$ & 14.16 & 14.33 & 13.49 & 13.82 & 14.61 & 12.79 & 14.69 & 14.42 & 13.47 & 13.68 & 14.58 & 14.72 & 16.04 \\
\hline $\mathrm{Fe}_{2} \mathrm{O}_{3} \ldots \ldots \ldots \ldots \ldots \ldots$ & 1.64 & 2.02 & - & - & 1.26 & 1.45 & 2.48 & 3.54 & 4.61 & 5.26 & 2.36 & 3.46 & 2.62 \\
\hline $\mathrm{FeO}, \ldots \ldots \ldots, \ldots, \ldots, \ldots$ & 8.40 & 8.21 & $7.39^{*}$ & $10.20^{*}$ & 9.02 & 8.61 & 7.82 & 8.46 & 9.02 & 8.14 & 8.32 & 8.08 & 6.33 \\
\hline$\ldots \ldots \ldots+\ldots, \ldots+\cdots$, & 0.20 & 0.20 & 0.15 & 0.18 & 0.21 & 0.20 & 0.20 & 0.24 & 0.21 & 0.23 & 0.21 & 0.21 & 0.16 \\
\hline $\operatorname{MgO} \ldots \ldots \ldots \ldots \ldots \ldots \ldots$ & 8.84 & 8.59 & 5.76 & 8.08 & 9.00 & 12.04 & 8.00 & 6.69 & 6.33 & 4.84 & 9.75 & 7.55 & 10.45 \\
\hline $\mathrm{CaO} \ldots \ldots \ldots \ldots \ldots \ldots \ldots, \ldots$ & 11.03 & 10.72 & 6.70 & 9.77 & 9.43 & 9.96 & 11.70 & 11.34 & 10.98 & 9.80 & 11.05 & 11.57 & 12.58 \\
\hline $\mathrm{Na}_{2} \mathrm{O} \ldots \ldots \ldots \ldots \ldots \ldots \ldots$ & 1.64 & 2.06 & 2.41 & 2.10 & 1.70 & 1.00 & 0.97 & 2.28 & 2.47 & 2.78 & 1.68 & 2.21 & 1.53 \\
\hline $\mathrm{K}_{2} \mathrm{O} \ldots \ldots \ldots \ldots \ldots \ldots \ldots$ & 0.75 & 0.42 & 1.69 & 0.37 & 0.74 & 0.24 & 0.35 & 0.19 & 0.22 & 0.58 & 0.15 & 0.27 & 0.21 \\
\hline $\mathrm{P}_{2} \mathrm{O}_{5} \ldots \ldots \ldots \ldots \ldots \ldots \ldots \ldots$ & 0.15 & 0.14 & 0.16 & 0.15 & 0.13 & 0.13 & 0.13 & 0.16 & 0.24 & 0.27 & 0.10 & 0.17 & 0.06 \\
\hline $\mathrm{H}_{2} \mathrm{O}^{+}$. & - & - & - & - & - & - & - & - & - & - & 2.43 & 1.28 & 1.88 \\
\hline \multirow[t]{2}{*}{ 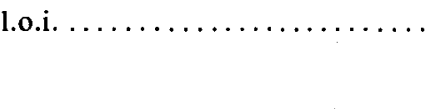 } & 2.97 & 1.55 & 1.20 & 1.51 & 2.39 & 5.48 & 4.76 & 1.41 & 1.22 & 1.01 & $0.55 \dagger$ & $0.68 \dagger$ & $0.28 \dagger$ \\
\hline & 99.80 & 99.76 & 99.99 & 99.89 & 99.55 . & 99.92 & 99.71 & 99.73 & 100.11 & 100.02 & 99.60 & 99.96 & 99.56 \\
\hline Total $\mathrm{Fe}$ as $\mathrm{FeO}$. & 9.88 & 10.03 & 7.39 & 10.20 & 10.15 & 9.92 & 10.05 & 11.65 & 13.17 & 12.87 & 10.44 & 11.19 & 8.69 \\
\hline $\mathrm{Cr}$ in ppm $\ldots \ldots \ldots \ldots \ldots \ldots$ & 605 & 589 & 418 & 596 & 511 & 1127 & 413 & 307 & 127 & 52 & 470 & 207 & 422 \\
\hline $\begin{array}{l}\mathrm{Mg} /(\mathbf{M g}+\text { Fetotal }) \\
\text { (in cation \%) } \ldots \ldots \ldots \ldots \ldots \ldots\end{array}$ & 0.62 & 0.60 & 0.58 & 0.58 & 0.54 & 0.68 & 0.59 & 0.51 & 0.46 & 0.40 & 0.62 & 0.55 & 0.68 \\
\hline \multicolumn{14}{|l|}{ CIPW norm (in weight \%) } \\
\hline $\mathrm{Q} \ldots \ldots \ldots \ldots \ldots \ldots$ & - & 0.20 & 13.90 & 2.87 & 0.95 & - & 2.39 & 0.31 & 0.04 & 3.08 & - & - & - \\
\hline or & 4.43 & 2.48 & 9.99 & 2.19 & 4.37 & 1.42 & 2.07 & 1.12 & 1.30 & 3.43 & 0.89 & 1.60 & 1.24 \\
\hline$a b$. & 13.88 & 17.43 & 20.39 & 17.77 & 14.38 & 8.46 & 8.21 & 19.29 & 20.90 & 23.52 & 14.22 & 18.70 & 12.95 \\
\hline & 29.06 & 28.61 & 21.00 & 27.19 & 30.05 & 29.70 & 34.70 & 28.55 & 25.02 & 23.14 & 31.80 & 29.45 & 36.28 \\
\hline di . & 20.06 & 19.25 & 9.21 & 16.69 & 12.91 & 15.22 & 18.36 & 21.99 & 23.20 & 19.81 & 18.19 & 22.03 & 20.79 \\
\hline hy ..... & 22.10 & 24.85 & 21.83 & 28.61 & 29.09 & 32.61 & 23.90 & 20.90 & 20.52 & 18.02 & 19.93 & 14.69 & 8.54 \\
\hline & 2.09 & - & - & - & - & 2.29 & - & - & - & - & 7.09 & 5.86 & 14.09 \\
\hline $\mathrm{mt} \ldots \ldots \ldots$ & 1.88 & 1.93 & - & - & 1.94 & 1.90 & 1.91 & 2.23 & 2.52 & 2.46 & 2.00 & 2.15 & 1.67 \\
\hline
\end{tabular}




\begin{tabular}{|c|c|c|c|c|c|c|c|c|c|c|c|c|c|}
\hline il $\ldots \ldots \ldots \ldots \ldots \ldots \ldots \ldots \ldots$ & 2.94 & 3.08 & 2.11 & 2.72 & 3.17 & 2.54 & 3.00 & 3.36 & 4.60 & 4.58 & 2.18 & 2.94 & 1.56 \\
\hline ap $\ldots \ldots \ldots \ldots \ldots \ldots \ldots \ldots \ldots \ldots$ & 0.36 & 0.33 & 0.38 & 0.36 & 0.31 & 0.31 & 0.31 & 0.38 & 0.52 & 0.64 & 0.24 & 0.40 & 0.14 \\
\hline $\begin{array}{l}\text { Katanormative plagioclase } \\
\text { composition as per cent }\end{array}$ & & & & & & & & & & & & & \\
\hline of anorthite $\ldots \ldots \ldots \ldots \ldots \ldots$ & 66.36 & 60.71 & 49.25 & 59.04 & 66.29 & 76.70 & 79.96 & 58.28 & 53.02 & 48.12 & 67.81 & 59.76 & 72.56 \\
\hline
\end{tabular}

"Containing but not analysed for Fe metal.

$\dagger$ loss on ignition minus $\mathrm{H}_{2} \mathrm{O}^{+}$.

$1 \quad 176562$ Olivine microporphyritic basalt with cognate inclusions from pahoehoe tongues of lava below thick iron-bearing lava. Base of Niaqussat member. Cleft at $435 \mathrm{~m}, 3.5 \mathrm{~km}$ west of Sarqardlît silardlît, outer Mellemfjord.

2176565 Olivine and plagioclase microporphyrtitic, iron-free basalt from the base of the composite iron-bearing lava of Niaqussat member. Locality as 176562.

3176564 Iron-bearing intermediate rock from $2 \mathrm{~m}$ above the base of the composte iron lava of Niaqussat member. Locality as 176562 .

$4 \quad 176574$ Iron-bearing basalt, slightly iron cumulative. $40 \mathrm{~cm}$ above base of iron lava at the base of Niaqussat member. At $285 \mathrm{~m}$ in large cleft just north of the river outlet at Eqaluit.

5176596 Olivine microporphyritic basalt from lava with characteristic flow folding and indications of inhomogeneity. Niaqussat member. Locality as 176574 at $460 \mathrm{~m}$.

6176642 Olivine microporphyritic basalt from the base of pahoehoe

7176641 Olivine microporphyritic basalt, centre of pahoehoe tongue. Niaqussat member. Locality as 176642 , at $620 \mathrm{~m}$.

8176595 Feldspar-olivine glomeroporphyritic tholeiitic basalt from Niaqussat member. Locality as 176574 , at $492 \mathrm{~m}$.

9176621 Slightly plagioclase glomeroporphyritic basalt from Niaqussat member. On ridge NW of Sapernuvik above Paukarut at $398 \mathrm{~m}$.

10176590 Slightly feldsparphyric basalt from Niaqussat member. Locality as 176574 , at $610 \mathrm{~m}$.

$11 \quad 176614$ Olivine porphyritic basalt from the upper part of Niaqussat member. Locality as 176621 , at $580 \mathrm{~m}$.

12176608 Olivine and plagioclase porphyritic basalt from the upper part of Niaqussat member. Locality as 176621 , at $600 \mathrm{~m}$.

$13 \quad 176611$ Olivine and plagioclase porphyritic basalt with globular structures on weathered surfaces. Uppermost exposed lava of Niaqussat member. Locality as 176621 , at $640 \mathrm{~m}$. lava. Niaqussat member. Eastern ridge towards point 661 at Kingigtûssaq at $415 \mathrm{~m}$. South coast of Nordfjord.

Norms have been calculated with $\mathrm{Fe}_{2} \mathrm{O}_{3} / \mathrm{FeO}=0.15$. This ratio is found in glassy feldsparphyric basalts of the Rinks Dal member and in basaltic glasses separated from these samples.

In no. 3 and 4 iron has been given as total iron $=\mathrm{FeO}$ and norms were calculated accordingly. The samples contain native iron, some $\mathrm{Fe} 2 \mathrm{O}_{3}$ and sulphides; sulphur not analysed.

Analyst: GGU's chemical laboratory, except for $\mathrm{Cr}$ and $\mathrm{P}_{2} \mathrm{O}_{5}$. 


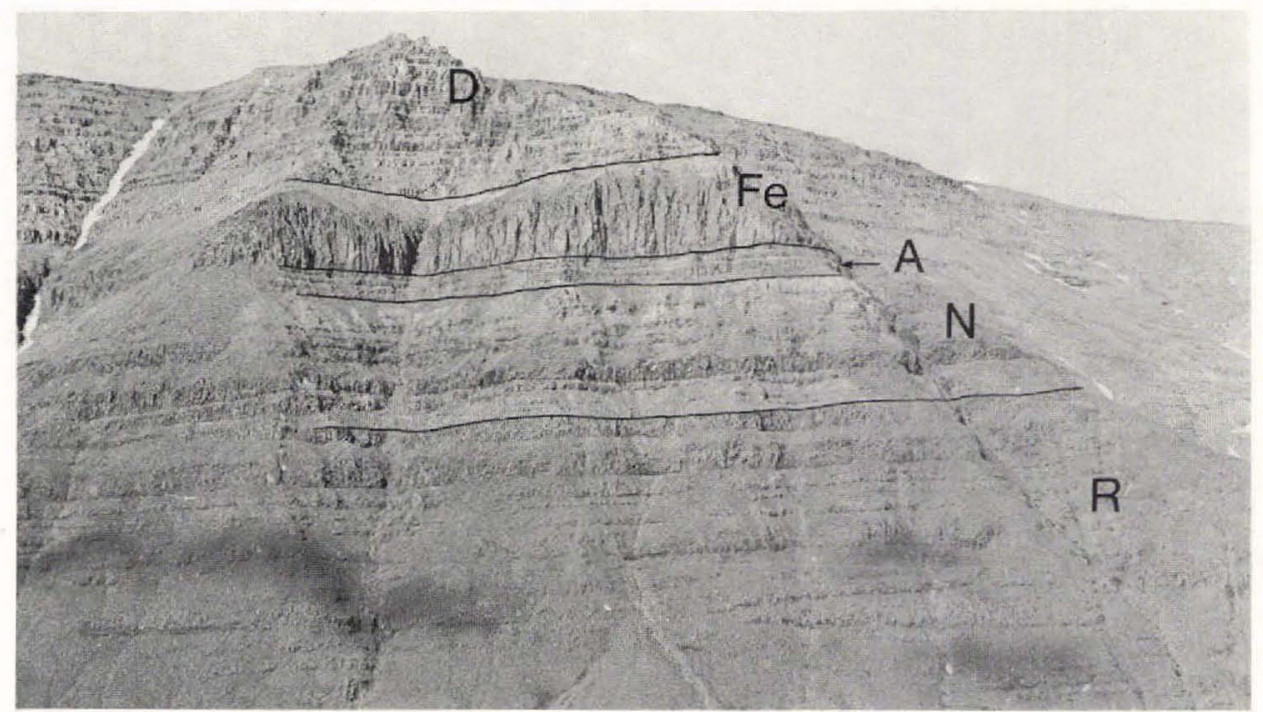

Fig. 21. The thick iron-bearing lava flow (Fe) at the base of the Niaqussat member as exposed west of Sarqardlît silardlît, Mellemfjord. The lava is here about $85 \mathrm{~m}$ thick and columnar jointed, the columns being several metres across. Three to four thin lava flows just below the colomnade possibly originated at the start of the eruption. R: Rinks Dal member basalt, N: Nordfjord member lavas, A: thin lava flows below the iron-bearing lava flow, Fe: the iron-bearing lava flow of the Niaqussat member,

D: Niaqussat member basalts.

The thick iron-bearing lava flow of Mellemfjord shows the same change of magma composition during an eruption as recorded from iron-bearing lavas and composite dykes elsewhere on Disko, (Pedersen, 1975b) and enables the eruption to be pictured thus:

An olivine tholeiitic melt flowed from subcrustal source regions upwards and was trapped in a reservoir in Mesozoic to early Tertiary carbonaceous shale and sandstone sediments. If the accumulated plateau basalts at this stage had reached a thickness of about 3 $\mathrm{km}$ and the underlying sediments were around $2 \mathrm{~km}$ thick, then the reservoir area can be estimated to have been about 3 to $5 \mathrm{~km}$ below the palaeosurface. In this area large scale reaction between sediments and magma took place and a large magma chamber was eventually formed, possibly of a tabular horizontal shape with a large magma-sediment contact surface. Considerable magma movements must have occurred within the reservoir to produce the large masses of fairly well homogenized strongly contaminated magma prior to eruption. Continuous or intermittent upflow from the source region, combined with build up of gas pressure originating from the reaction with sediments led finally to an apparently exhaustive eruption, when the magma chamber volume was above $14-15 \mathrm{~km}^{3}$. The low viscosity olivine tholeiitic magma, forming the least contaminated part of the chamber and possibly newly arrived from the source, reached the earth's surface before the much more voluminous masses of intermediate, iron-bearing, viscous magma. The density contrast between the denser basalt and less dense intermediate rock may well have helped the outflow of the siliceous magma masses which flowed on top of the still liquid and much less viscous tholeiitic basalt. 


\section{Aphyric, olivine microporphyritic and feldsparphyric basalts}

The iron-bearing lava is covered by a sequence of basaltic lavas some $300 \mathrm{~m}$ thick which just cap the mountain tops or are removed in the eastern part of the area. Towards the south-west a complete section is exposed through these lavas. Exposures of the lavas can be followed towards the north for more than $60 \mathrm{~km}$ along the west coast of Disko, forming the youngest exposed rocks there. Details of the sequence are presented in fig. 17.

A few 'aphyric' basalts cover the iron-bearing lava and single aphyric basalt lavas occur here and there in the sequence. They are 10 to $30 \mathrm{~m}$ thick aa lavas, which are probably sediment contaminated. Hardly any are truly aphyric when inspected under the microscope but may contain traces of microphenocrystic plagioclase and pyroxenes.

Olivine microporphyritic basalts occur at several levels in the sequence. Most characteristic are two to three extensive lava flows, found at levels of about $150 \mathrm{~m}$ above the iron-bearing lava in the southern part of the area. They may exceed $30 \mathrm{~m}$ in thickness and display a characteristic flow folding pattern. The lavas seem to have been inhomogeneous and of very similar type to demonstrably sediment-contaminated basalts from the same part of the Niaqussat member of north-western Disko.

Petrographically the lavas carry microphenocrystic olivine, often pseudomorphed, and plagioclase. Chromite is rarely found enclosed in olivines. Scattered highly modified sediment xenoliths and xenocrysts may occur. A chemical analysis (Table 8, no. 5) shows a quartz normative basalt fairly rich in $\mathrm{MgO}$ and $\mathrm{K}_{2} \mathrm{O}$. Presumably the composition has been modified by reaction with sediments.

Further north, the number of olivine microporphyritic lavas increases and reaches a maximum in the peninsula between Nordfjord and Mellemfjord. Here a monotonous sequence of about 50 thin olivine-rich pahoehoe lavas form a most characteristic greyish weathering marker horizon. These olivine-rich lavas carry numerous microphenocrysts of olivine, often pseudomorphed, which may include brownish semiopaque chromite. Microphenocrystic plagioclase laths are found in addition. Some of the lavas contain abundant modified sediment xenoliths. Chemical analyses of two olivine-rich basalts, fairly zeolite rich, are presented in Table 8, no. 6 and 7. Both analyses have a high loss on ignition and show compositions from just olivine normative to quartz normative, very likely modified by sediment contamination (and possibly also by alteration).

Feldsparphyric basalts are widespread within this sequence and vary in thickness from less than 5 to $40 \mathrm{~m}$. The lavas are aa flows. The basalts carry phenocrysts of plagioclase, olivine (often pseudomorphed) and augite which vary in size from less than $1 \mathrm{~mm}$ to a few millimetres and in amount from nearly nil to 10-15 per cent. Chemical analyses of three lavas are presented in Table 8, no. 8,9 and 10. The analyses are all quartz normative. Minor elements vary considerably in the rocks. Analysis 10 is high in silica compared with other tholeiitic basalts analysed from the province, while $\mathrm{Cr}$ is very low, indicating that the rock is extensively fractionated.

\section{Olivine porphyritic basalts}

Olivine porphyritic basalts form the youngest lavas exposed on Disko. Only a few flows, in total about $70 \mathrm{~m}$ thick, have been preserved. They cap the lava plateau around Kingigtup qáqâ, south-west of Mellemfjord, where they have been mapped (Plate 1). The lavas are 
massive columnar jointed plateau basalts with aa tops. The rocks differ in appearance from the underlying flows in having a more fine-grained groundmass and in containing scattered dolerite or gabbroic cognate inclusions. The not very abundant phenocrysts, which may occasionally exceed $5 \mathrm{~mm}$ in size, are olivine, plagioclase and augite. Chromite seems to be lacking.

Three chemical analyses (Table 8, no. 11, 12 and 13) show the lavas to be slightly to distinctly olivine normative tholeiitic basalts. Analysis 11 is remarkably poor in $\mathrm{TiO}_{2}$ and shows similarity to olivine-poor basalts from the lower part of the Vaigat Formation of northern Disko and to basalts from mid-oceanic ridges. Even more extreme is the top lava (analysis 13), which is as poor in $\mathrm{TiO}_{2}$ and $\mathrm{P}_{2} \mathrm{O}_{5}$ as the lower Vaigat Formation picrites. The rock, which is non-cumulative, shows a high normative anorthite component. The chemical features indicate that melting or remelting of sources depleted in several elements may have played a role in the genesis of these rocks.

\section{Summary}

Summing up the Niaqussat member volcanism and referring again to fig. 17 it is possible to generalize:

(1) The Niaqussat member was characterized by upwelling of olivine tholeitic melts, more magnesian than the Rinks Dal member basalts, along a zone extending for at least $60-70 \mathrm{~km}$, covering an area of at least $1400 \mathrm{~km}^{2}$, possibly much more.

(2) Some magmas reached the surface and erupted as pahoehoe lavas resembling the Vaigat Formation picrites (Clarke \& Pedersen, 1976), but with a lower MgO content.

(3) Under stagnating eruptive conditions some of the magma was possibly modified to produce feldsparphyric quartz normative basalts.

(4) The volcanism had a somewhat cyclic character with feldsparphyric basalts following more magnesian-rich magma. The late olivine porphyritic basalts were possibly the first part of such a cycle.

(5) The quartz normative character of most of the Niaqussat member rocks, even the fairly magnesian-rich rocks, indicates that most of the magma was accumulated in highlevel reservoirs during the upflow, and the scattered sediment derived xenoliths and xenocrysts suggest varying chemical additions to the basalts. The highly contaminated iron-bearing lava was an extreme product of such reactions.

(6) The late olivine porphyritic basalt resembling basalts from the mid-oceanic ridges (MORB) is unique for the Maligat Formation of West Greenland and resembles in type of occurrence the plateau basalts of the upper series from the Tertiary of the Faeroe Islands (Noe-Nygaard \& Rasmussen, 1968; Bollingberg et al., 1975), where olivine tholeiites resembling MORB basalts overlie more evolved feldsparphyric tholeiitic basalts.

The lavas of south-west Disko substantiate the findings of Hald (1976) from Nûgssuaq, that the Maligât Formation basalts occur as thick lava sequences, all of which cannot have evolved through a single fractionation in a crustal or shallow subcrustal regime. Evidence for upwelling of several pulses of magmas with affinities to picrite basalts of the Vaigat Formation of northern Disko is indicated. Considerable lateral regional variations in composition must have existed in plateau basalts erupted at largely the same time. 


\section{Alteration of the volcanic rocks}

The lava sequence has, like all Tertiary volcanic rocks of West Greenland, been affected by circulating water. The resulting alteration is strongly dependent on rock porosity, so that vesicular lava tops may show abundant growth of zeolites and green, sheet silicate minerals. More siliceous rock types typically carry agates and other silica precipitates. Massive flows may still have empty vesicles. Most rock samples show minor traces of zeolites and sheet silicates, but very fine-grained or glassy rocks may still be extremely fresh and the iron-bearing lava samples have typically preserved phases like troilite and ferrite which are easily affected by weathering and hydrothermal alteration.

Hyaloclastic breccias show abundant zeolites and zones of palagonitized glass fragments, but have still cores with fresh glass and well preserved olivine.

Neither fossil hot springs nor traces of zones of flow of hot water were found, and it is concluded that in most parts of the lava sequence samples can be obtained suitable for detailed chemical and petrographical work. This is shown by most but not all of the analysed samples.

\section{Structure}

As evident from the description of the lavas and the map (Plate 1), the emplacement of the lavas occurred over a nearly horizontal surface. Although small-scale faulting and jointing is likely to have occurred simultaneously with the volcanism, no such movements have been demonstrated in the field. If regional movements occurred during the volcanism, as is recorded in northern Disko (Pedersen, 1973; Geological map sheet 1:100 00070 V. 1, S, Qutdligssat), these movements did not involve significant relative tilting within the area mapped.

The continuous lava plateau was later cut into a number of blocks, but numerous detailed photogrammetrical measurements rarely show substantial fault movements; those detected have mostly had a maximum downthrow of about $50 \mathrm{~m}$, normally much less. The fracture and fault intensity varies over the area. Most prominent is a N-S system cutting the central part of Mellemfjord and another through the outermost north coast of Mellemfjord around Jernpynten.

In most of the area mapped, the strike and dip of the lavas varies only slightly, the strike from N-S to NW-SE, and dips from $1^{\circ}$ to about $5^{\circ} \mathrm{W}$. Towards the east the lava plateau becomes nearly horizontal. Two schematic E-W sections, shown in Plate 1, display the structure very well. The sections show only limited displacement along individual faults. Measurements of the cumulative fault movements from widely spaced points on the marker horizons indicate only very small hidden displacements in valleys and fjords.

Thus it seems that the outer, western plateau has been affected by a slow sinking of the coast area compared to the plateau extending across the Disko gneiss ridge to the east. Within the area mapped, the cumulative sinking was of the order of $800 \mathrm{~m}$ along an E-W section of $18 \mathrm{~km}$. Fig. 22 shows a typical part of the westerly dipping plateau.

A structural break occurs towards the north-west, around Jernpynten, where extensive faulting has cut the plateau into blocks with lavas dipping around $12^{\circ} \mathrm{W}$. This is the southernmost extension of the extensive zone of faulting and down-sagging found along the west coast of Disko, described and pictured by Henderson (1973) and Pedersen (1975a, plate 2). 


\section{References}

Bollingberg, H., Brooks, C. K. \& Noe-Nygaard, A. 1975: Trace element variations in Faeroese basalts and their possible relationships to ocean floor spreading history. Bull. geol. Soc. Denmark, $24,55-60$.

Clarke, D. B. 1975: Tertiary basalts dredged from Baffin Bay. Can. J. Earth Sci. 12, 1396-1405.

Elder, J. W. 1975: A seismic and gravity study of the western part of the Cretaceous-Tertiary sedimentary basin of central west Greenland. Rapp. Grønlands geol. Unders. 69, 5-9.

Hald, N. 1976: Early Tertiary flood basalts from Hareøen and western Nûgssuaq, West Greenland. Bull. Grønlands geol. Unders. 120, $36 \mathrm{pp.}$

Hald, N. \& Pedersen, A. K. 1975: Lithostratigraphy of the early Tertiary volcanic rocks of central West Greenland. Rapp. Grønlands geol. Unders. 69, 17-24.

Henderson, G. 1973: The geological setting of the West Greenland basin in the Baffin Bay region. Pap. geol. Surv. Can. 71-23, 521-544.

Lorenzen, I. 1882: Kemisk Undersøgelse af det metalliske Jern fra Grønland samt nogle af de dermed følgende Bjergarter. Meddr Grønland 4, 133-172.

Nicolau, T. 1900: Untersuchungen an den eisenführenden Gesteinen der Insel Disko. Meddr Grønland 24, 216-248.

Noe-Nygaard, A. \& Rasmussen, J. 1968: Petrology of a 3000 metre sequence of basaltic lavas in the Faeroe Islands. Lithos 1, 286-304.

Pauly, H. 1969: White cast iron with cohenite, schreibersite and sulphides from Tertiary basalts on Disko, Greenland. Meddr dansk geol. Foren. 19, 8-26.

Pedersen, A. K. 1973: Report on field work along the north coast of Disko, 1971. Rapp. Gronlands geol. Unders. 53, 21-27.

Pedersen, A. K. 1975a: New mapping in north-western Disko 1972. Rapp. Grønlands geol. Unders. 69, 25-32.

Pedersen, A. K. 1975b: New investigations of the native iron-bearing volcanic rocks of Disko, central West Greenland. Rapp. Gronlands geol. Unders. 75, 48-51.

Steenstrup, K. J. V. 1882: Om Forekomsten af Nikkeljern med Widmannstättenske Figurer i Basalten i Nord-Grønland. Meddr Grønland 4, 113-132.

Steenstrup, K. J. V. 1883: Beretning om Undersøgelsesrejserne i Nord-Grønland i Aarene 1878-80. Meddr Grønland 5, 1-41.

Steenstrup, K. J. V. 1900: Beretning om en Undersøgelsesrejse til Øen Disko i Sommeren 1898. Meddr Grønland 24, 249-306. 